\title{
Effect of API-1 and FR180204 on cell proliferation and apoptosis in human DLD-1 and LoVo colorectal cancer cells
}

\author{
ATIYE SEDA YAR SAGLAM ${ }^{1}$, EBRU ALP $^{2}$, ZUBEYIR ELMAZOGLU $^{1}$ and EMINE SEVDA MENEVSE ${ }^{1}$ \\ ${ }^{1}$ Department of Medical Biology and Genetics, Faculty of Medicine, Gazi University, Besevler, Ankara 06500; \\ ${ }^{2}$ Department of Medical Biology, Faculty of Medicine, Giresun University, Giresun 28200, Turkey
}

Received August 5, 2015; Accepted July 15, 2016

DOI: $10.3892 / \mathrm{ol} .2016 .4995$

\begin{abstract}
The activation of the phosphatidylinositol-3 kinase/v-akt murine thymoma viral oncogene homolog (Akt) and mitogen activated protein kinase kinase/extracellular signal-regulated kinase (ERK) pathways are implicated in the majority of cancers. Selective inhibition of Akt and ERK represents a potential approach for cancer therapy. Therefore, the present study aimed to investigate the apoptotic and anti-proliferative effects of the novel and selective Akt inhibitor 4-amino-5,8-dihydro-5-oxo-8- $\beta$-D-ribofuranosyl-pyrido[2,3-d]pyrimidine-6-carboxamide (API-1) and selective ERK1/2 inhibitor FR180204 (FR) alone and in combination on colorectal cancer (CRC) cells (DLD-1 and LoVo). In addition, the effects of API-1 and FR on Akt and ERK signaling pathways were also investigated. The effects of the agents on DLD-1 and LoVo cells were evaluated in terms of cell viability, cytotoxicity, DNA synthesis rate, DNA fragmentation and caspase-3 activity levels. In addition, quantitative reverse transcription-polymerase chain reaction and western blot analysis were performed to examine relevant mRNA and protein levels. The present study observed that the combination of FR with API-1 resulted in significant apoptosis and cytotoxicity compared with any single agent alone in a time-dependent manner in these cells. Also, treatment with FR and API-1 in combination decreased the expression levels of B-cell lymphoma-2 (BCL2), Bcl-2-like 1, cyclin D1 and cMYC, and increased the expression levels of BCL2-associated $\mathrm{X}$ protein and BCL2 antagonist/killer via phosphorylated Akt and phosphorylated ERK1/2 downregulation. The combination of Akt and ERK1/2 inhibitors resulted in enhanced apoptotic and anti-proliferative effects against CRC cells. The present study hypothesizes that the combination of FR and API-1 in
\end{abstract}

Correspondence to: Dr Atiye Seda Yar Saglam, Department of Medical Biology and Genetics, Faculty of Medicine, Gazi University, Besevler, Ankara 06500, Turkey

E-mail: atiyeseda@yahoo.com

Key words: FR180204, API-1, colorectal cancer, apoptosis, Akt, ERK1/2
CRC cells may contribute toward potential anti-carcinogenic effects. Additional analyses using other cancer cell lines and animal models are required to confirm these findings in vitro and in vivo.

\section{Introduction}

Colorectal carcinoma (CRC) is one of the most common types of malignancy and has a poor prognosis (1). It is a major cause of cancer-associated morbidity and mortality worldwide, and the incidence of this disease has gradually increased in recent years $(1,2)$. The development of CRC is associated with genetic and epigenetic factors, resulting in changes in the expression of various oncogenes, which are tumor suppressor genes that lead to dysregulation of intestinal epithelial cell proliferation, survival, differentiation and apoptosis $(1,3,4)$.

The phosphatidylinositol-3 kinase (PI3K)/v-akt murine thymoma viral oncogene homolog (Akt) and the mitogen activated protein kinase (MAPK), also termed Raf-MAPK kinase (MEK)-extracellular signal-regulated kinase (ERK), signaling pathways are commonly dysregulated and hyperactivated in cancers, including CRC, by genetic and epigenetic aberrations (4-8). Due to the fact that suppression of the PI3K/Akt and MAPK/ERK signaling pathways leads to the blockade of cell proliferation, these cascades are important during cancer development for the control of cell cycle progression and cell growth (6-10).

Akt, a serine-threonine protein kinase, is a downstream effector and central signaling molecule in the PI3K pathway and plays an important role in controlling the balance between cell survival and apoptosis $(11,12)$. Aberrant cell growth and survival may be promoted by the PI3K pathway due to Akt phosphorylation (12). In addition, the PI3K/Akt signaling pathway is frequently activated in numerous types of human cancers, including CRC, and has been linked to cancer development $(10,13,14)$.

The MAPK/ERK pathway is also a major signal transduction cascade for cellular processes, such as cell proliferation, cell cycle progression, survival, differentiation and apoptosis $(15,16)$. Activation of MAPK signaling results in increased phosphorylation and activation of ERK1/2, which in turn, phosphorylates several proteins associated with cell cycle progression and cell motility (17). In addition, this signaling pathway is critical for development and 
progression of human cancers and results in increased cancer cell proliferation, resistance to apoptosis, and therefore, tumor growth $(18,19)$.

Certain studies demonstrated that cancer development may be stopped or slowed down by inhibition of these signal transduction pathways, such as PI3K/Akt and MAPK/ERK (14,19-21). These pathways have been attractive therapeutic targets in the treatment of CRC and numerous compounds inhibit these signaling pathways at several levels; therefore, they may be considered potentially useful for CRC treatment $(7,8,22)$. Selective inhibition of Akt and ERK represents a potential approach for the treatment of CRC. The small molecule Akt/protein kinase B inhibitor, 4-amino-5,8-dihydro-5-oxo-8- $\beta$-D-ribofuranosyl-pyrido[2,3-d]pyrimidine-6-carboxamide (API-1) is a novel and potent selective inhibitor of Akt signaling that binds to the pleckstrin homology $(\mathrm{PH})$ domain of Akt and blocks its membrane translocation, which leads to inhibition of Akt-regulated cell growth and cell survival in vitro and in vivo $(23,24)$. Additionally, FR180204 (FR) is a potent and selective adenosine triphosphate (ATP)-competitive inhibitor of ERK1 and ERK2, and inhibits the kinase activity of ERK1 and ERK2 (25).

In the present study, the role of Akt and ERK in cell growth and apoptosis was focused on in DLD-1 and LoVo cell lines using the specific Akt inhibitor API-1 and ERK1/2 inhibitor FR. In addition, the present study aimed to investigate the possible synergistic apoptotic and antiproliferative effects of a novel combination of API-1 and FR in CRC cells and their effects on PI3K and MAPK signaling pathways, including changes in the mRNA and protein expression levels of these cascade components.

\section{Materials and methods}

Chemicals and antibodies. The reagents used in the present study were purchased from the following suppliers: FR and API-1 from Tocris Bioscience (Bristol, UK); RPMI-1640 medium, fetal bovine serum (FBS), L-glutamine and penicillin/streptomycin from Gibco (Thermo Fisher Scientific, Inc., Waltham, MA, USA); water soluble tetrazolium-1 (WST-1), Cytotoxicity Detection Kit Plus, Cell Proliferation ELISA colorimetric kit and Cell Death Detection ELISA Plus kit from Roche Diagnostics GmbH (Mannheim, Germany); and PathScan ${ }^{\circledR}$ Cleaved Caspase-3 (Asp175) Sandwich ELISA kit and monoclonal rabbit antibodies against $\beta$-actin (ACTB; catalog no., 4970; dilution, 1:1,000), B-cell lymphoma-2 (BCL2)-associated X protein (BAX; catalog no., 5023; dilution, 1:1,000), BCL2 antagonist/killer (BAK; catalog no., 12105; dilution, 1:1,000), cyclin D1 (CYCD1; catalog no., 2978; dilution, 1:1,000), cMYC (catalog no., 13987; dilution, 1:1,000), Akt (catalog no., 4685; dilution, 1:1,000), ERK1/2 (catalog no., 4370; 1:2,000), phosphorylated Akt (pAkt; catalog no., 4060; dilution, 1:2,000), phosphorylated ERK1/2 (pERK1/2; catalog no., 4094; dilution, 1:1,000) and horseradish peroxidase (HRP)-conjugated anti-rabbit IgG secondary antibody (catalog no., 7074; dilution, 1,1000) were provided by Cell Signaling Technology (Danvers, MA, USA). All other chemicals and reagents were obtained from Sigma-Aldrich (St. Louis, MO, USA).
Cell culture. The human CRC DLD-1 (catalog no., CCL-221; American Type Culture Collection, Manassas, VA, USA) and LoVo (catalog no., CCL-229; American Type Culture Collection) cell lines were cultured in RPMI-1640 medium containing 10\% FBS, 2 mM L-glutamine, $100 \mathrm{U} / \mathrm{ml}$ penicillin and $100 \mu \mathrm{g} / \mathrm{ml}$ streptomycin. The cells were maintained in a humidified atmosphere incubator at $37^{\circ} \mathrm{C}$, with a $5 \% \mathrm{CO}_{2}$ atmosphere. FR and API-1 were dissolved in dimethyl sulfoxide (DMSO) to make $1 \mathrm{mM}$ stock solutions that were kept at $-20^{\circ} \mathrm{C}$. The stock solutions were freshly diluted with cell culture medium to the required concentration immediately prior to use. The final concentration of DMSO in culture medium during the treatment of cells did not exceed $0.5 \%$ $(\mathrm{v} / \mathrm{v})$.

Cell viability and apoptotic analyses. To detect the effect of FR and API-1 on cell viability following treatment, a WST-1 cell proliferation assay was performed. In brief, DLD-1 and LoVo cells were seeded into 96 -well plates $\left(1 \times 10^{4}\right.$ cells/well) containing $100 \mu \mathrm{l}$ of the growth medium in the absence or presence of increasing concentrations of FR (1-150 $\mu \mathrm{M})$ and API-1 $(0.1-100 \mu \mathrm{M})$ and then incubated at $37^{\circ} \mathrm{C}$ and $5 \% \mathrm{CO}_{2}$ for 24 and $48 \mathrm{~h}$. At the end of the incubation period, the medium was removed, $100 \mu 1$ WST-1 was added and the cell solution was incubated at $37^{\circ} \mathrm{C}$ for $4 \mathrm{~h}$. Formazan dye produced by viable cells was quantified by measuring absorbance at a wavelength of $450 \mathrm{~nm}$ using a microplate reader (Spectramax M3; Molecular Devices, Sunnyvale, CA, USA). All experiments were performed four times and the experiment was repeated twice.

Fluorescence microscopic analysis of cell death. Cell death was assessed using ethidium bromide (EB) and acridine orange (AO) staining. The DLD-1 and LoVo cells were plated in 24-well plates at a concentration of $2 \times 10^{5}$ cells/well and incubated at $37^{\circ} \mathrm{C}$ for $24 \mathrm{~h}$. Following exposure of the cells to FR $(10 \mu \mathrm{M})$, API-1 $(0.5 \mu \mathrm{M}$ or $2 \mu \mathrm{M}$ for DLD- 1 cells and $0.5 \mu \mathrm{M}$ or $1 \mu \mathrm{M}$ for LoVo cells) or a combination of the two for 24 and $48 \mathrm{~h}$, cells were harvested and cell suspensions (supernatants) were collected and then centrifuged at $130 \mathrm{x} g$ for $5 \mathrm{~min}$. The pellet was resuspended in $25 \mu \mathrm{l}$ cold phosphate-buffered saline (PBS) buffer and $4 \mu \mathrm{l} \mathrm{AO/EB}$ dye mix $(100 \mu \mathrm{g} / \mathrm{ml}$ in PBS). The stained cell suspensions $(10 \mu \mathrm{l})$ were placed on a microscope slide and covered with a coverslip. The stained cells were examined under a fluorescence microscope (Olympus, Tokyo, Japan) and images were captured to determine the presence of apoptotic cells. To determine the apoptotic index, the number of apoptotic cells (yellowish-orange cells) was divided by the total number of counted cells and multiplied by 100 to calculate the percentage of apoptotic cells.

Lactate dehydrogenase $(\mathrm{LDH})$ release assay. The release of $\mathrm{LDH}$, a marker of cytotoxicity, from treated DLD-1 and LoVo cells was measured using the Cytotoxicity Detection Kit Plus, according to the manufacturer's protocol. Briefly, cells were treated with FR $(10 \mu \mathrm{M})$, API-1 $(0.5 \mu \mathrm{M}$ or $2 \mu \mathrm{M}$ for DLD-1 cells and $0.5 \mu \mathrm{M}$ or $1 \mu \mathrm{M}$ for LoVo cells) or a combination of the two for 24 and $48 \mathrm{~h}$. To determine the release of LDH, the supernatant of treated cells was transferred to a 96-well plate. At the end of the period, the absorbance of the samples was 
Table I. Gene-specific primer sequences and UPL probe numbers used in quantitative reverse transcription-polymerase chain reaction.

\begin{tabular}{clc}
\hline Gene & \multicolumn{1}{c}{ Primer sequence (5'-3') } & $\begin{array}{c}\text { UPL probe } \\
\text { number }\end{array}$ \\
\hline $\begin{array}{l}\text { GAPDH } \\
\text { Forward }\end{array}$ & AGCCACATCGCTCAGACAC & 60 \\
Reverse & GCCCAATACGACCAAATCC & \\
BCL2 & & 75 \\
Forward & AGTACCTGAACCGGCACCT & 75 \\
Reverse & GCCGTACAGTTCCACAAAGG & \\
BCL2L1 & & 28 \\
Forward & AGCCTTGGATCCAGGAGAA & \\
Reverse & GCTGCATTGTTCCCATAGAGT & \\
BAX & & 57 \\
Forward & ATGTTTTCTGACGGCAACTTC & 56 \\
Reverse & ATCAGTTCCGGCACCTTG & \\
BAK & & \\
Forward & AAACTGGGCTCCCACTCA & 66 \\
Reverse & CAGTGGAGGACGGGATCA & \\
BIM & & \\
Forward & CATCGCGGTATTCGGTTC & 70 \\
Reverse & GCTTTGCCATTTGGTCTTTTT & \\
CYCD1 & & \\
Forward & TGTCCTACTACCGCCTCACA & 16 \\
Reverse & CAGGGCTTCGATCTGCTC & \\
cMYC & & \\
Forward & GCTGCTTAGACGCTGGATTT & 66 \\
Reverse & TAACGTTGAGGGGCATCG & \\
\hline
\end{tabular}

GAPDH, glyceraldehyde-3-phosphate dehydrogenase; BCL2, B-cell lymphoma-2; BCL2L1, BCL2 like 1; BAX, BCL2-associated X protein; BAK, BCL2 antagonist/killer; BIM, BCL2-like 11; CYCD1, cyclin D1; UPL, universal probe library.

measured at a wavelength of $490 \mathrm{~nm}$ using the Spectramax M3 microplate reader. The level of released LDH from treated LoVo and DLD-1 cells was expressed as a percentage of the positive control (2\% Triton X-100).

Cell proliferation assay. The bromodeoxyuridine (BrdU) assay is an immunoassay for the quantification of BrdU incorporation into newly synthesized DNA of actively proliferating cells $(26,27)$. Cell proliferation was measured using the BrdU cell proliferation enzyme-linked immunosorbent assay (ELISA). DLD-1 and LoVo cells $\left(1 \times 10^{4}\right.$ cells/well) were incubated in 96-well plates for $24 \mathrm{~h}$ and then treated with various selected concentrations of FR $(10 \mu \mathrm{M})$ and/or API-1 $(0.5 \mu \mathrm{M}$ or $2 \mu \mathrm{M}$ for DLD-1 cells and $0.5 \mu \mathrm{M}$ or $1 \mu \mathrm{M}$ for LoVo cells) for 24 and $48 \mathrm{~h}$. Culture medium (RPMI-1640) was used as a control. Cell proliferation was quantified by the measurement of BrdU incorporation during DNA synthesis, according to the manufacturer's protocol, using the Spectramax M3 microplate reader at $450 \mathrm{~nm}$.
DNA fragmentation analysis. The quantitative DNA fragmentation assay, a marker for apoptosis, was performed using the Cell Death Detection ELISA Plus kit, according to the manufacturer's protocol. Briefly, the cells were plated into 96 -well plates at a density of $2 \times 10^{4}$ cells/well in $200 \mu \mathrm{l}$ RPMI-1640 medium and incubated overnight at $37^{\circ} \mathrm{C}$. Subsequently, the cells were treated with FR or API-1 for 24 and $48 \mathrm{~h}$ at $37^{\circ} \mathrm{C}$. Following the ELISA procedure, performed according to the manufacturer's protocol, cytoplasmic histone-associated DNA fragments were measured at $405 \mathrm{~nm}$ using the Spectramax M3 microplate reader. The results are represented as the mean enrichment factor [absorbance of the treated (apoptotic) cells/absorbance of the untreated (control) cells].

Caspase-3 activity assay. To verify the presence of caspase-3 activity, which is an important sign of apoptosis, in the cells, a caspase-3 activity assay was performed using the PathScan ${ }^{\circledR}$ Cleaved Caspase-3 (Asp175) Sandwich ELISA kit, according to the manufacturer's protocol. Briefly, following treatment with either FR $(10 \mu \mathrm{M})$ and API-1 $(0.5 \mu \mathrm{M}$ or $2 \mu \mathrm{M}$ for DLD-1 cells and $0.5 \mu \mathrm{M}$ or $1 \mu \mathrm{M}$ for LoVo cells) alone or in combination at the indicated concentrations for 24 and $48 \mathrm{~h}$, protein content of cell lysates was determined using a bicinchoninic acid (BCA) protein assay kit (Pierce, Rockford, IL, USA). At the end of this period, the absorbance of the cleaved caspase-3 levels was measured at $405 \mathrm{~nm}$ using the Spectramax M3 microplate reader.

Quantitative reverse transcription-polymerase chain reaction (RT-PCR) analysis. Total RNA was extracted from each sample using High Pure RNA Isolation kit (Roche Diagnostics GmbH), according to the manufacturer's protocol. Equal amounts of RNA were then reverse transcribed into complementary DNA (cDNA) using Transcriptor First Strand cDNA Synthesis kit (Roche Diagnostics GmbH). Quantitative RT-PCR was performed using a LightCycler ${ }^{\circledR} 480$ instrument (Roche Diagnostics $\mathrm{GmbH}$ ) with Light Cycler 480 Probes Master mix (Roche Diagnostics $\mathrm{GmbH}$ ), according to the manufacturer's protocol. Gene-specific intron spanning primers and probes were designed using the online Universal Probe Library (UPL) Assay Design Center (Roche Diagnostics GmbH). The sequences of the primers and UPL numbers are shown in Table I. The mRNA level of glyceraldehyde-3-phosphate dehydrogenase was used to normalize the levels of the genes of interest. Each sample was tested in triplicate. Fold change in BCL2, BCL2L1, BAX, BAK, BCL2-like 11 (BIM), CYCD1 and cMYC gene expressions were calculated using the $2^{-\Delta \Delta C q}$ method (28) and significant differences were identified using a Student's t-test on normalized Cq values.

Western blot analysis. The effects of FR, API-1 and a combination of the two on protein expression in LoVo and DLD-1 cells were determined using western blot analysis. Proteins were isolated from the cell lysate at the different time points and protein contents of each cell lysate were measured using BCA Protein Assay kit, according to the manufacturer's protocol. Western blotting was performed as previously described (29) Bands were visualized via an enhanced chemiluminescence (ECL) system (Kodak Gel Logic 2200 PRO 
Imaging System; Carestream Health, Rochester, NY, USA). The expression of the BAX, BAK, CYCD1, cMYC, Akt, pAkt, ERK1/2 and pERK1/2 proteins was normalized against a loading control, $\beta$-actin. The Kodak Gel Logic 2200 PRO Imaging System Software semiquantitatively detects protein bands against loading control densitometrically and provides relative band signals.

Statistical analysis. Quantitative data were represented as the mean \pm standard deviation. The differences between groups were assessed for statistical significance using Student's $t$-test. $\mathrm{P}<0.05$ was considered to indicate a statistically significant difference. All studies were repeated in at least 3 independent experiments. Calculations of relative mRNA expression levels of BCL2, BCL2 like 1 (BCL2L1), BAX, BAK, BAD, BIM, CYCD1 and cMYC were performed using Relative Expression Software Tool 2009 v2.0.13 (Qiagen, Hilden, Germany) (30).

\section{Results}

Effects of FR and API-1 alone and in combination on the viability of LoVo cells. To evaluate the effects of FR and API-1 on the viability of human CRC cells, DLD-1 and LoVo cells were exposed to increasing concentrations of FR $(1-150 \mu \mathrm{M})$ and API-1 (0.1-100 $\mu \mathrm{M})$ for 24 and $48 \mathrm{~h}$. FR and API-1 each decreased cell proliferation in a time- and dose-dependent manner. As shown in Fig. 1A and D, while $30 \%$ of the cells were determined as viable in LoVo cells, viability of DLD-1 cells was found to be almost $50 \%$ at the highest concentration of FR $(150 \mu \mathrm{M})$ at 24 and $48 \mathrm{~h}$ compared with the untreated controls. The half-maximal inhibitory concentration $\left(\mathrm{IC}_{50}\right)$ value of FR was $150 \mu \mathrm{M}$ for 24 and $48 \mathrm{~h}$ in DLD-1 cells (Fig. 1A). The $\mathrm{IC}_{50}$ value of FR was also found to be $80 \mu \mathrm{M}$ for $24 \mathrm{~h}$ and $40 \mu \mathrm{M}$ for $48 \mathrm{~h}$ in LoVo cells (Fig. 1D). The present study also examined the effect of API-1 on DLD-1 and LoVo cells. Cell viability of LoVo and DLD-1 cells was found to be 46 and $53 \%$ at the highest concentration of API-1 $(100 \mu \mathrm{M})$ at $24 \mathrm{~h}$, respectively (Fig. $1 \mathrm{~B}$ and $\mathrm{E})$. The $\mathrm{IC}_{50}$ value of API-1 was $100 \mu \mathrm{M}$ for $24 \mathrm{~h}$ and $4 \mu \mathrm{M}$ for $48 \mathrm{~h}$ for DLD-1 cells (Fig. 1B). The $\mathrm{IC}_{50}$ value of API-1 was also $20 \mu \mathrm{M}$ for $24 \mathrm{~h}$ and $4 \mu \mathrm{M}$ for $48 \mathrm{~h}$ for LoVo cells (Fig. 1E).

To study antiproliferative effects of combined treatment with FR and API-1, DLD-1 and LoVo cells were exposed to $10 \mu \mathrm{M}$ FR at various concentrations of API-1 $(0.5-4 \mu \mathrm{M})$ for 24 and 48 h. Combined treatment with FR and API-1 also resulted in dose-dependent reduction of DLD-1 and LoVo cell viability (Fig. 1C and F). The results revealed that the cell viability was 81,75 and $57 \%$ in DLD-1 cells treated with $10 \mu \mathrm{M}$ FR and $0.5,1$ or $2 \mu \mathrm{M}$ API-1, respectively, at $24 \mathrm{~h}$. The cell proliferation decreased 75,66 and $64 \%$ in DLD-1 cells treated with $10 \mu \mathrm{M}$ FR and $0.5,1$ or $2 \mu \mathrm{M}$ API-1, respectively, compared with untreated controls at 48 h (Fig. 1C). In LoVo cells, cell viability was 85,60 and $58 \%$ in cells treated with $10 \mu \mathrm{M}$ FR and $0.5,1$ or $3 \mu \mathrm{M}$ API-1, respectively, at $24 \mathrm{~h}$. Following treatment for $48 \mathrm{~h}$ with $10 \mu \mathrm{M}$ FR and $0.5,1$ or $3 \mu \mathrm{M}$ API-1, cell viability was 69,52 and $50 \%$, respectively, in LoVo cells (Fig. 1F).

Morphological analysis by fluorescence microscopy. To identify whether FR and/or API-1 induced apoptosis or necrosis, double-staining using $\mathrm{AO} / \mathrm{EB}$ was performed using fluorescence microscopy. As shown in representative images (Fig. 2), morphological findings indicated that treatment with FR and API-1 alone induced apoptosis in DLD-1 and LoVo cells. In LoVo cells, $10 \mu \mathrm{M}$ FR significantly increased the percentage of apoptotic cells in a time-dependent manner $(\mathrm{P}=0.02)$. Additionally, $0.5 \mu \mathrm{M}$ API-1 had no significant effects in the two cell lines. However, at concentrations of $1 \mu \mathrm{M}$ API-1 in LoVo cells and $2 \mu \mathrm{M}$ API-1 in DLD-1 cells, the percentages of apoptotic cells were significantly increased at $48 \mathrm{~h}$ ( $\mathrm{LoVo}, \mathrm{P}=0.005$; DLD-1, $\mathrm{P}=0.016$ ). Following treatment for 24 and $48 \mathrm{~h}$, LoVo and DLD-1 cells treated with FR + API-1 showed an increased number of apoptotic cells in a dose- and time-dependent manner. The maximal apoptotic death was observed in LoVo cells treated with $10 \mu \mathrm{M}$ FR and $1 \mu \mathrm{M}$ API-1 and DLD-1 cells treated with $10 \mu \mathrm{M}$ FR and $2 \mu \mathrm{M}$ API-1 (DLD-1 at $24 \mathrm{~h}$, $\mathrm{P}=0.005$ and $48 \mathrm{~h}, \mathrm{P}=0.011$; LoVo at $24 \mathrm{~h}, \mathrm{P}=0.003$ and $48 \mathrm{~h}$, $\mathrm{P}=0.002$ ).

Cytotoxic effects of treatment with FR and API-1 alone or in combination. To determine the cytotoxic effects of FR and API-1 on DLD-1 and LoVo cell lines, the cells were incubated with FR and API-1 alone or in combination for 24 and $48 \mathrm{~h}$ using an LDH assay. The results of these assays showed that there were time- and dose-dependent increases in cytotoxicity, particularly in the LoVo cell line. As shown in Fig. 3A, treatment with $2 \mu \mathrm{M}$ API-1 caused an increase in cytotoxicity at $24 \mathrm{~h}$ in DLD-1 cells $(\mathrm{P}=0.027)$, whereas treatment with $10 \mu \mathrm{M}$ FR alone for $48 \mathrm{~h}$ increased cytotoxic effects compared with control LoVo cells. Treatment with $1 \mu \mathrm{M}$ API-1 alone also caused a time-dependent increase in cytotoxicity in LoVo cells ( 24 h, P=0.007; 48 h, P=0.005; Fig. 3B). The results revealed that FR + API-1 exhibited a cytotoxic effect in a dose-dependent manner in terms of the two cell lines. As shown in Fig. 3, the highest cytotoxicity rate in DLD-1 cells was observed following treatment with $10 \mu \mathrm{M}$ FR and $2 \mu \mathrm{M}$ API-1 $(24 \mathrm{~h}$, $\mathrm{P}=0.005 ; 48 \mathrm{~h}, \mathrm{P}=0.012$ ), and the highest cytotoxicity rate in LoVo cells was observed following treatment with $10 \mu \mathrm{M} \mathrm{FR}$ and $1 \mu \mathrm{M}$ API-1 for $24 \mathrm{~h}(\mathrm{P}=0.003)$ and $48 \mathrm{~h}(\mathrm{P}=0.002)$.

Effect of FR and API-1 alone or in combination on DNA synthesis. To determine the antiproliferative effects of FR and API-1 on DLD-1 and LoVo cell lines, DNA synthesis was measured by BrdU assay. Treatment with FR and API-1 alone inhibited DNA synthesis in a dose-dependent manner at 24 and $48 \mathrm{~h}$, particularly in LoVo cell lines. Incubation with $10 \mu \mathrm{M}$ FR significantly reduced the DNA synthesis rate in LoVo cells at 24 and $48 \mathrm{~h}(\mathrm{P}=0.001)$, but the DNA synthesis rate of DLD-1 cells was only reduced by treatment with $10 \mu \mathrm{M}$ FR for $24 \mathrm{~h}(\mathrm{P}=0.002)$ (Fig. 4A and $\mathrm{B})$. Treatment with $1 \mu \mathrm{M}$ API-1 alone also significantly reduced the DNA synthesis rate in a time-dependent manner in LoVo cells $(\mathrm{P}=0.001)$. Treatment of LoVo cells with $10 \mu \mathrm{M}$ FR and $1 \mu \mathrm{M}$ API-1 and DLD-1 cells with $10 \mu \mathrm{M}$ FR and $2 \mu \mathrm{M}$ API-1 significantly reduced the DNA synthesis rate subsequent to 24 and $48 \mathrm{~h}(\mathrm{P}=0.001)$.

Effects of FR and API-1 alone or in combination on DNA fragmentation. To examine the possible apoptotic effects of treatment with FR and API-1 alone and in combination, the levels of mono-oligo nucleosome fragments were quantified 
DLD-1
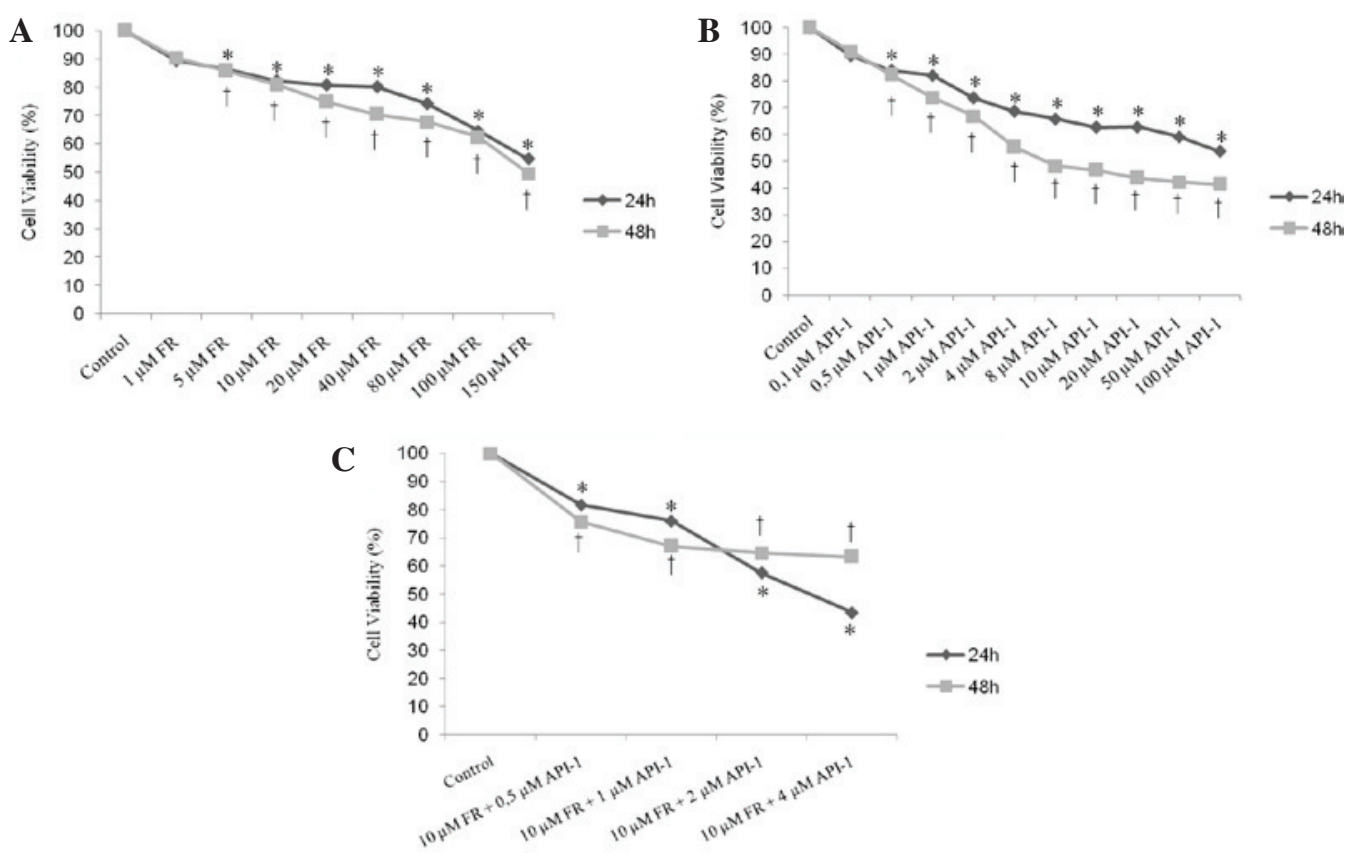

LoVo
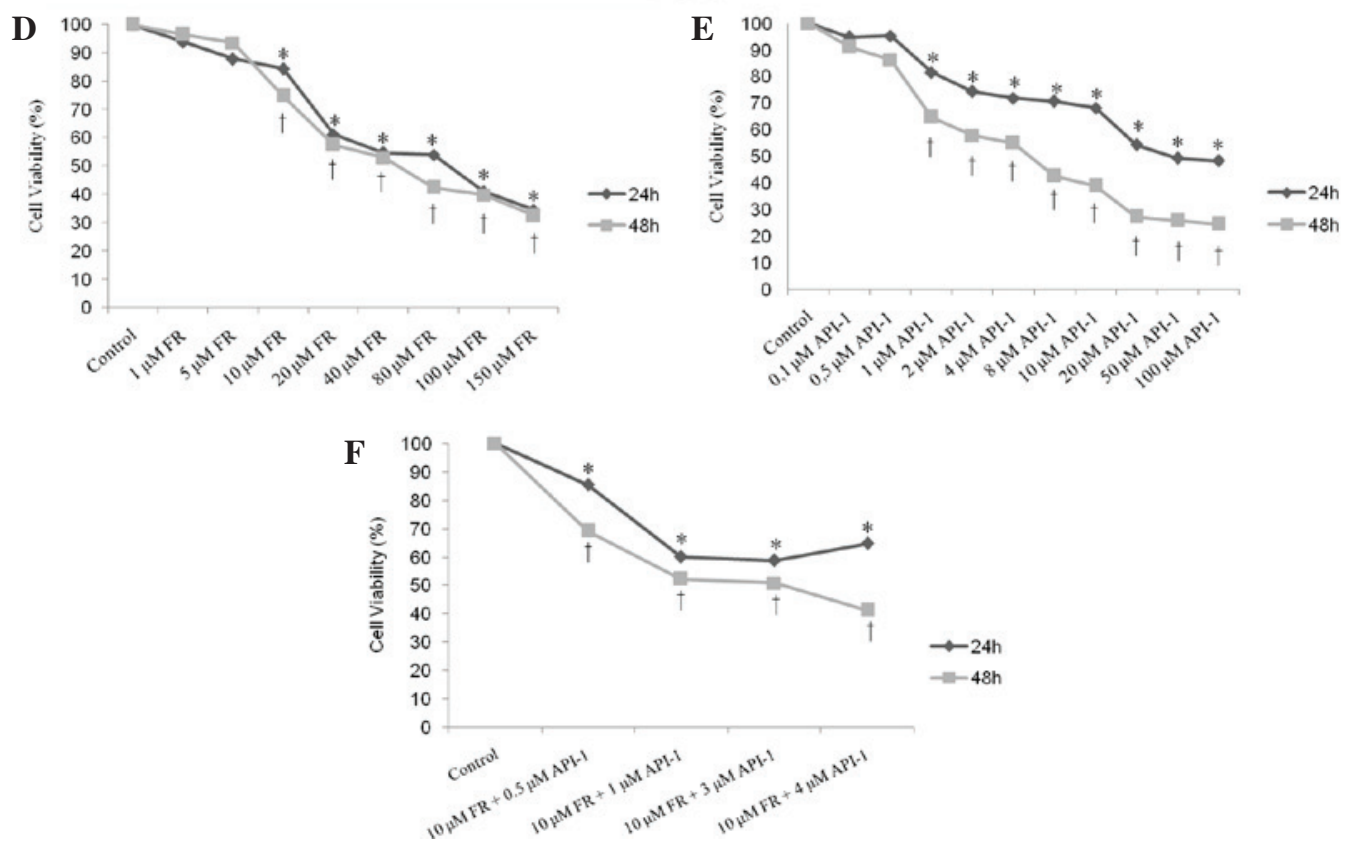

Figure 1. Effect of API-1 and FR alone and in combination on the viability of CRC cells. (A-C) DLD-1 and (D-F) LoVo cells were treated with FR and API-1 alone or in combination at various concentrations and time intervals, and their proliferation was assessed by water soluble tetrazolium-1 assay. The data were normalized to the viability of the control cells. The data were expressed as the mean \pm standard deviation of at least three independent experiments, each conducted in quadruplicate. Statistical significance was determined using two-way analysis of variance, ${ }^{\prime \prime} \mathrm{P}<0.05$ vs. control cells for $24 \mathrm{~h}$. ${ }^{\mathrm{t}} \mathrm{P}<0.05 \mathrm{vs}$. control cells for 48 h. FR, FR180204; API-1, 4-amino-5,8-dihydro-5-oxo-8- $\beta$-D-ribofuranosyl-pyrido[2,3-d]pyrimidine-6-carboxamide; DMSO, dimethyl sulfoxide.

using Cell Death Detection ELISA assay. DLD-1 and LoVo cells were treated with different concentrations of FR $(10 \mu \mathrm{M})$ and API- $1(0.5 \mu \mathrm{M}$ or $2 \mu \mathrm{M}$ for DLD- 1 cells and $0.5 \mu \mathrm{M}$ or $1 \mu \mathrm{M}$ for LoVo cells) alone or in combination for 24 and $48 \mathrm{~h}$ prior to analyzing DNA fragmentation. The results showed that treatment with FR alone elevated the DNA fragmentation rate at 24 and $48 \mathrm{~h}$ in DLD-1 and LoVo cells when compared with the control cells (DLD-1, $\mathrm{P}=0.001$; LoVo, $\mathrm{P}=0.001$ ). In the DLD-1 and LoVo cell lines, a dose- and time dependent increase in apoptotic cells was detected following treatment with API-1 alone. When LoVo cells were exposed to $10 \mu \mathrm{M}$ FR and $1 \mu \mathrm{M}$ API-1, there was a 10.6-fold increase in DNA fragmentation observed at $48 \mathrm{~h}$ compared with untreated controls (Fig. 5A and B). Additionally, subsequent to $10 \mu \mathrm{M}$ FR and $2 \mu \mathrm{M}$ API-1 treatment, the DNA fragmentation rate of DLD-1 cells increased 6.26 fold at $24 \mathrm{~h}$. The highest fragmentation rate was observed for the aforementioned $10 \mu \mathrm{M} \mathrm{FR}$ and $1 \mu \mathrm{M}$ API-1 concentrations for $48 \mathrm{~h}$ in LoVo cells $(\mathrm{P}=0.001)$ and 
A
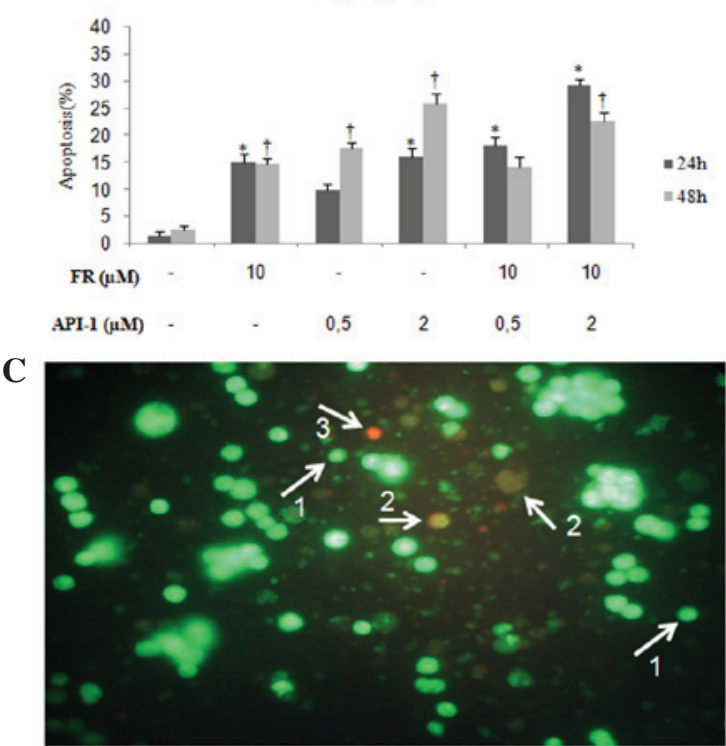
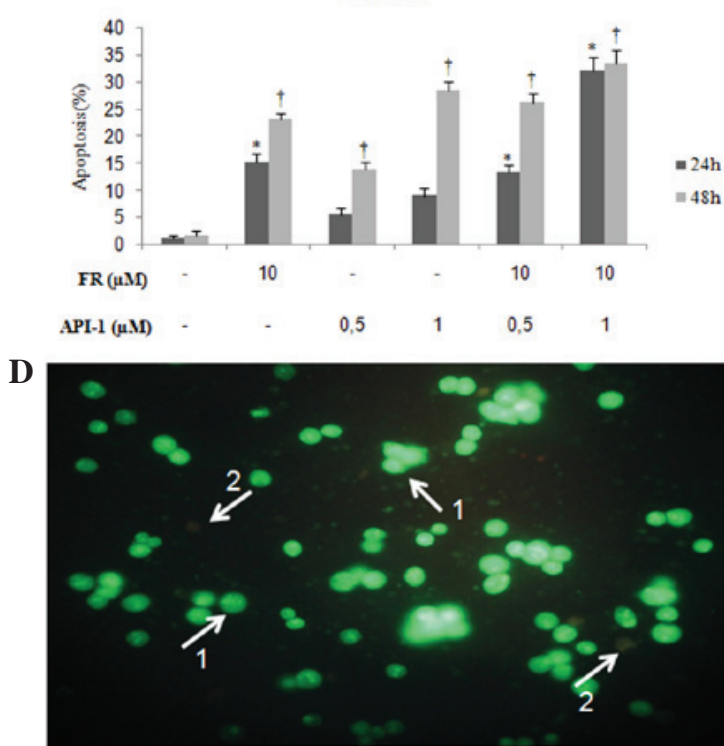

Figure 2. Apoptotic ratios of (A) DLD-1 and (B) LoVo cells treated with API-1 and FR alone or in combination for 24 and 48 h. (C and D) Representative images of (1) viable, (2) apoptotic and (3) necrotic cells were determined by acridine orange/ethidium bromide staining using flourescent microscopy at x40 magnification. (C) DLD-1 cells treated with $2 \mu \mathrm{M}$ API-1 at $24 \mathrm{~h}$. (D) LoVo cells treated with $1 \mu \mathrm{M}$ API-1 at $24 \mathrm{~h}$. ${ }^{*} \mathrm{P}<0.05 \mathrm{vs}$. control cells for $24 \mathrm{~h}$. ${ }^{\dagger} \mathrm{P}<0.05$ vs. control cells for 48 h. FR, FR180204; API-1, 4-amino-5,8-dihydro-5-oxo-8- $\beta$-D-ribofuranosyl-pyrido[2,3-d]pyrimidine-6-carboxamide.

$10 \mu \mathrm{M}$ FR and $2 \mu \mathrm{M}$ API-1 concentrations for $24 \mathrm{~h}$ in DLD-1 cells $(\mathrm{P}=0.002)($ Fig. 5).

Treatment with FR and API-1 alone or in combination induced caspase-3 cleavage. Cleaved caspase-3 protein levels were examined by ELISA to assess caspase activity, in order to determine the nature of apoptosis induction by treatment with FR and API-1 alone and in combination. Following treatment with $10 \mu \mathrm{M}$ FR, caspase-3 activity was found to be increased in LoVo cells at $48 \mathrm{~h}$ and DLD-1 cells at $24 \mathrm{~h}$ post-treatment. Cleaved caspase- 3 protein levels increased in a dose- and time-dependent manner following API-1 treatment in LoVo cells (Fig. 6). In addition, the combination of FR and API-1 caused a significant increase in cleaved caspase-3 levels in LoVo cells subsequent to 24 and $48 \mathrm{~h}$ of treatment $(24 \mathrm{~h}$, $\mathrm{P}=0.001$; 48 h, $\mathrm{P}=0.001$ ) (Fig. 6B). However, in DLD-1 cells, caspase-3 activity was only significantly increased subsequent to $24 \mathrm{~h}$ of treatment with FR and API-1 alone or in combination (FR, P=0.001; API-1, P=0.001). Co-treatment with FR and API-1 at the highest concentration in these cells markedly induced cleaved caspase-3 levels compared with FR and API-1 treatment alone (DLD-1 at $24 \mathrm{~h}, \mathrm{P}=0.001$; LoVo at $24 \mathrm{~h}$ and 48 h, $\mathrm{P}=0.01$ ) (Fig. 6A).

Expression of BCL2, BCL2L1, BAX, BAK, BIM, CYCD1 and cMYC in FR and API-1-treated cells. The mRNA levels of BCL2, BCL2L1, BAX, BAK, BIM, CYCD1 and cMYC were evaluated by quantitative RT-PCR. It was found that treatment with FR and API-1 alone and in combination significantly downregulated the $\mathrm{BCL} 2$ (FR, $\mathrm{P}=0.001$; $\mathrm{API}-1, \mathrm{P}=0.001$; $\mathrm{FR}+\mathrm{API}-1$, $\mathrm{P}=0.022)$ and $\mathrm{BCL} 2 \mathrm{~L} 1$ ( $\mathrm{FR}, \mathrm{P}=0.001$; API-1, $\mathrm{P}=0.001$; $\mathrm{FR}+\mathrm{API}-1, \mathrm{P}=0.001)$ mRNA levels in LoVo cells. In addition, BCL2 and BCL2L1 mRNA levels were significantly decreased in DLD-1 cells subsequent to combined treatment with FR and API-1 (BCL2, P=0.027; BCL2L1, P=0.019). Compared with the controls, proapoptotic BAX (API-1, P=0.001; FR + API-1, $\mathrm{P}=0.033$ ), BAK (API-1, P=0.001; FR + API-1, $\mathrm{P}=0.049)$ and BIM (API-1, P=0.001; FR + API-1, P=0.033) mRNA levels were also significantly upregulated following treatment with $1 \mu \mathrm{M}$ API-1 and $10 \mu \mathrm{M}$ FR $+1 \mu \mathrm{M}$ API- 1 in LoVo cells. In DLD-1 cells, BAX mRNA levels were increased following treatment with API-1 alone and FR + API-1. In addition to BAX mRNA levels, combination treatment caused upregulation of BAK mRNA levels (Fig. 7A and B). Additionally, $10 \mu \mathrm{M}$ FR treatment did not significantly change BAX, BAK and BIM mRNA expression levels ( $\mathrm{P}>0.05)$. Compared to control cells, the CYCD1 mRNA levels were significantly decreased subsequent to combined treatment with FR and API-1 for $24 \mathrm{~h}$ $(\mathrm{P}=0.001)$, but not $48 \mathrm{~h}$, in LoVo cells $(\mathrm{P}>0.05)$. Significantly downregulated CYCD1 mRNA levels were also determined following combined treatment with FR and API-1 at 24 and $48 \mathrm{~h}$ in DLD-1 cells ( $24 \mathrm{~h}, \mathrm{P}=0.027 ; 48 \mathrm{~h}, \mathrm{P}=0.001)$. By contrast, Fig. 7 indicated that cMYC mRNA levels were significantly decreased subsequent to treatment with FR + API-1 for 24 and $48 \mathrm{~h}$ in LoVo and DLD-1 cells (DLD-1 at $24 \mathrm{~h}, \mathrm{P}=0.041$ and $48 \mathrm{~h}, \mathrm{P}=0.001$; LoVo at $24 \mathrm{~h}, \mathrm{P}=0.031$ and $48 \mathrm{~h}, \mathrm{P}=0.021)$.

Effects of treatment with FR and/or API-1 on BAX, BAK, $C Y C D 1$ and $c M Y C$ protein levels. To investigate the effects of treatment with FR and API-1 alone and in combination on LoVo cells, the expression of BAX, BAK, CYCD1 and cMYC proteins was assessed by western blot analysis. The expression of CYCD1 and cMYC proteins was consistent with results from quantitative RT-PCR analysis. As illustrated in Fig. 8, while FR and API-1 had no significant effects on the levels of CYCD1 and cMYC, combination treatment of the two agents resulted in a marked reduction of CYCD1 and cMYC at 24 and $48 \mathrm{~h}$ in LoVo and DLD-1 cells. Additionally, in comparison with the mRNA expression levels, there was an induction in BAK and BAX proteins in the DLD-1 and LoVo cells. 
A

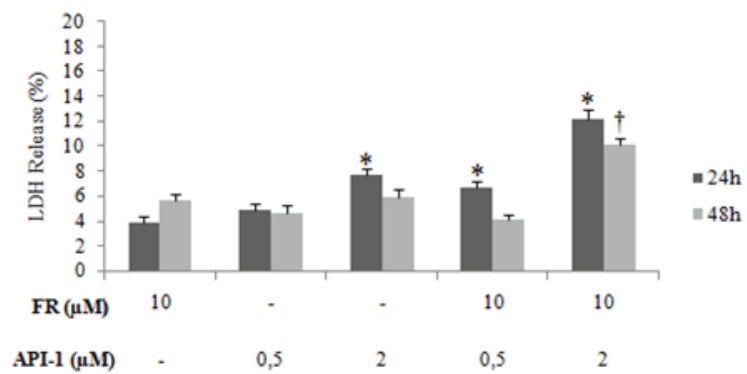

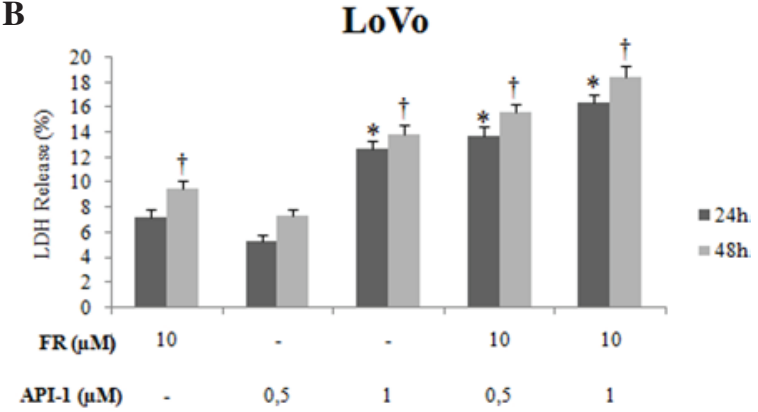

Figure 3. Cytotoxicity of treatment with FR and API-1 alone or in combination was evaluated by LDH release from (A) DLD-1 and (B) LoVo cells subsequent to 24 and $48 \mathrm{~h}$ of incubation. The LDH release assays were performed using triplicate samples in three independent experiments. Statistical significance was determined using two-way analysis of variance, ${ }^{*} \mathrm{P}<0.05$ vs. control cells for $24 \mathrm{~h} .{ }^{\dagger} \mathrm{P}<0.05$ vs. control cells for $48 \mathrm{~h}$. LDH, lactate dehydrogenase; FR, FR180204; API-1, 4-amino-5,8-dihydro-5-oxo-8- $\beta$-D-ribofuranosyl-pyrido[2,3-d]pyrimidine-6-carboxamide.

A

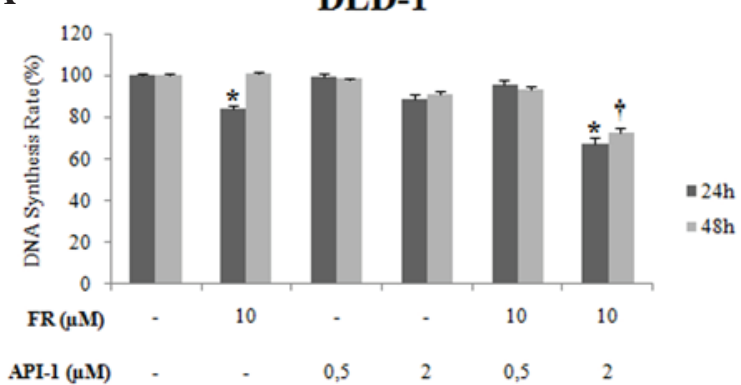

B

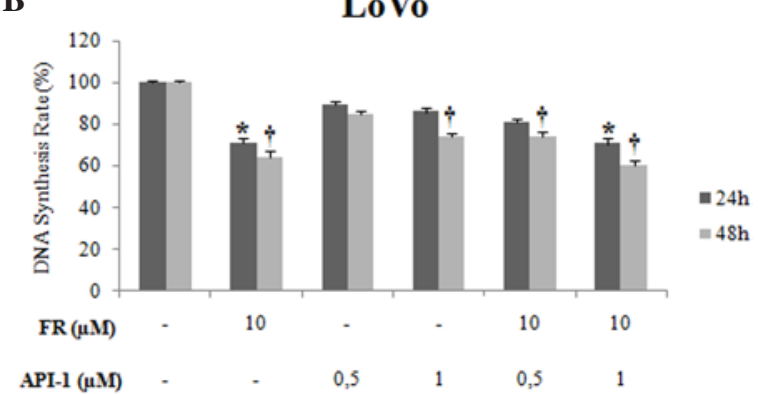

Figure 4. Effect of treatment with FR and API-1 alone or in combination on the DNA synthesis rate of (A) DLD-1 and (B) LoVo cells, as determined by the $\mathrm{BrdU}$ incorporation assay subsequent to 24 and $48 \mathrm{~h}$ exposure to the indicated concentrations $(\mu \mathrm{M})$ of the compounds. " $\mathrm{P}<0.05 \mathrm{vs}$. control cells for $24 \mathrm{~h}$. ${ }^{\dagger} \mathrm{P}<0.05$ vs. control cells for 48 h. BrdU, 5'-bromo-2'-deoxy-uridine; FR, FR180204; API-1, 4-amino-5,8-dihydro-5-oxo-8- $\beta$-D-ribofuranosyl-pyrido[2,3-d] pyrimidine-6-carboxamide.

A

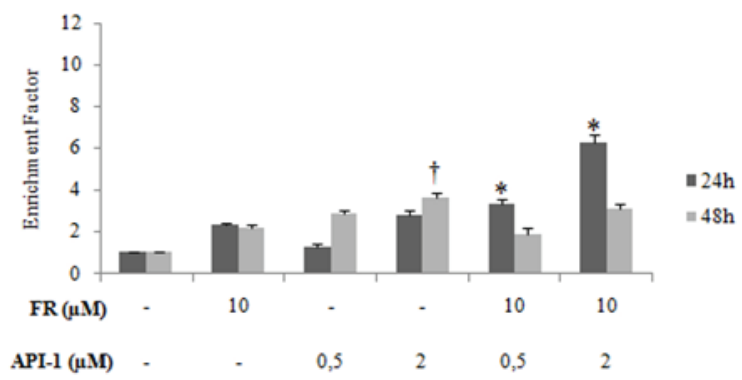

B

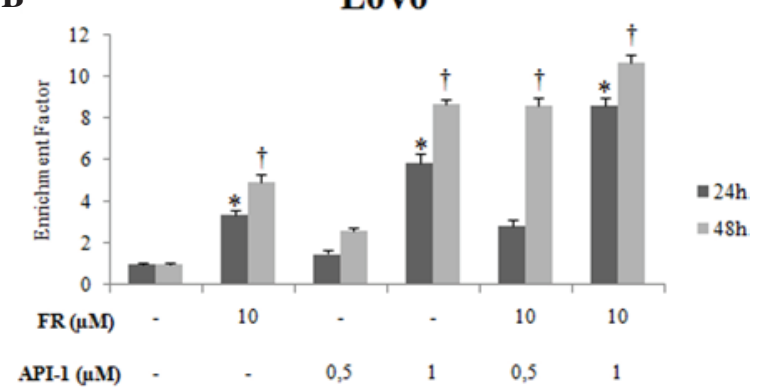

Figure 5. DNA fragmentation induced by treatment with selected doses of FR and API-1 alone or in combination in (A) DLD-1 and (B) LoVo cells. Effect of the agents on apoptosis was determined using the Cell Death Detection ELISA assay, which quantitatively detects cytosolic histone-associated DNA fragments. The data are expressed as the mean \pm standard deviation of three independent experiments. ${ }^{*} \mathrm{P}<0.05$ vs. control cells for $24 \mathrm{~h}$. ${ }^{\dagger} \mathrm{P}<0.05 \mathrm{vs}$. control cells for 48 h. ELISA, enzyme-linked immunosorbent assay; FR, FR180204; API-1, 4-amino-5,8-dihydro-5-oxo-8- $\beta$-D-ribofuranosyl-pyrido[2,3-d]pyrimidine-6-carboxamide.

Western blot analysis showed that treatment with API-1 alone increased the expression of BAK protein at $24 \mathrm{~h}$ in DLD-1 cells (Fig. 8A). Treatment with FR and API-1 alone for 24 and $48 \mathrm{~h}$ also upregulated the expression of BAK protein in LoVo cells (Fig. 8B). Additionally, the protein level of BAK was increased following combined treatment with FR and API-1 in these CRC cells at 24 and $48 \mathrm{~h}$. The western blot analysis also showed a similar trend between BAX protein levels and gene expression. As demonstrated in Fig. 8, the expression levels of BAX protein were upregulated in the presence of API-1 alone and FR + API-1 in these cells.
Effect of treatment with FR and API-1 alone or in combination on $p A k t$ and $p E R K 1 / 2$ protein levels. The present study investigated the effect of treatment with FR and API-1 for 24 and $48 \mathrm{~h}$ on the phosphorylation of Akt and ERK1/2 in LoVo and DLD-1 cells. As shown in Fig. 9, in the presence of FR, pERK1/2 expression was downregulated, while the expression of total ERK1/2 did not change. Additionally, the phosphorylation of ERK1/2 was also inhibited by treatment of cells with FR and API-1 in combination for 24 and $48 \mathrm{~h}$ (Fig. 9). Additionally, the total protein level of Akt did not alter following treatment with FR and API-1 alone or in 
A

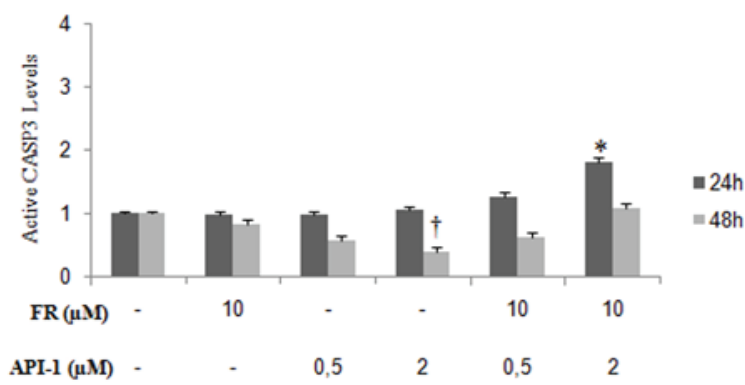

B

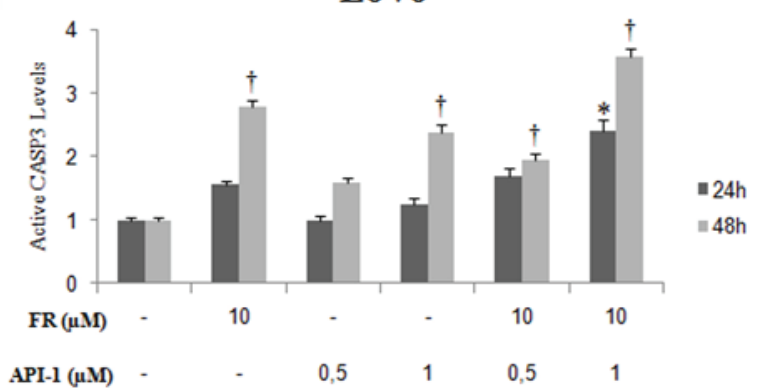

Figure 6. Effect of treatment with FR and API-1 alone or in combination on active caspase-3 protein levels in (A) DLD-1 and (B) LoVo cells, as measured by a colorimetric assay at 24 and 48 h. ${ }^{*} \mathrm{P}<0.05$ vs. control cells for $24 \mathrm{~h}$. ${ }^{\dagger} \mathrm{P}<0.05$ vs. control cells for 48 h. FR, FR180204; API-1, 4-amino-5,8-dihydro-5-oxo-8$\beta$-D-ribofuranosyl-pyrido[2,3-d]pyrimidine-6-carboxamide.

\section{DLD-1}

$\mathbf{A}$

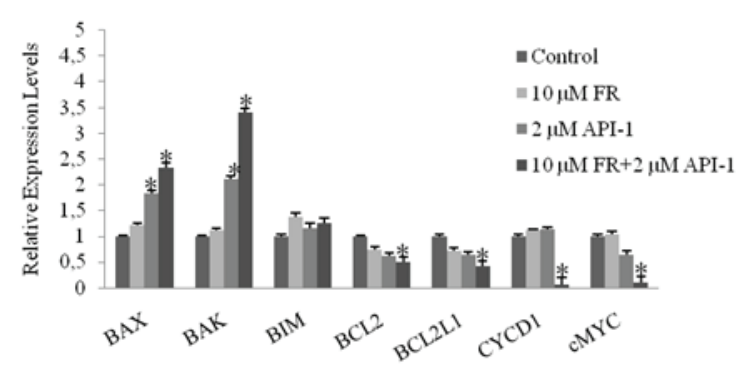

B

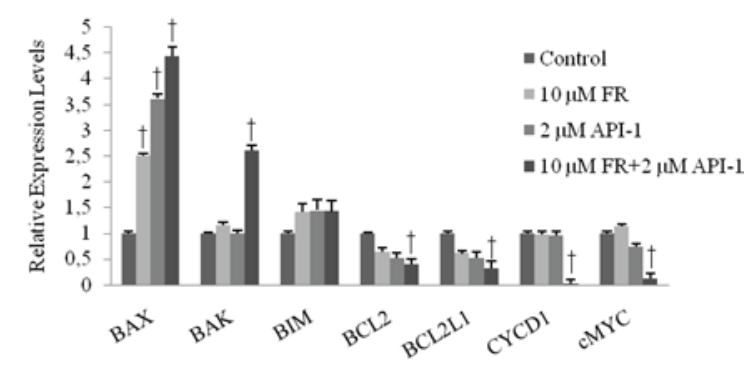

C

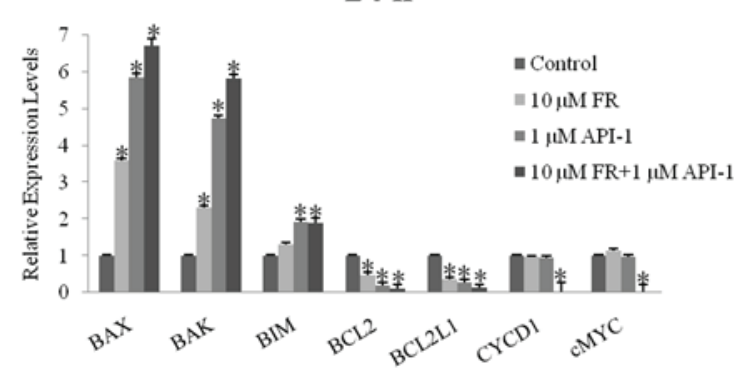

LoVo

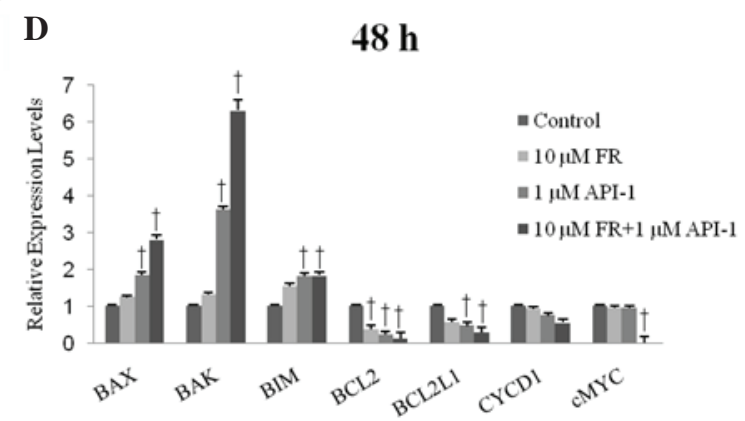

Figure 7. Quantitative reverse transcription-polymerase chain reaction was used to examine the mRNA expression levels of BCL2, BCL2L1, BAX, BAK, BİM, CYCD1 and cMYC genes subsequent to treatment with FR and API-1 alone or in combination for (A) $24 \mathrm{~h}$ and (B) $48 \mathrm{~h}$ in DLD-1 cells and (C) $24 \mathrm{~h}$ and (D) $48 \mathrm{~h}$ in LoVo cells. "P<0.05 vs. control cells for $24 \mathrm{~h}$. ${ }^{\dagger} \mathrm{P}<0.05$ vs. control cells for 48 h. mRNA, messenger RNA; FR, FR180204; API-1, 4-amino-5,8 -dihydro-5-oxo-8- $\beta$-D-ribofuranosyl-pyrido[2,3-d]pyrimidine-6-carboxamide; BCL2, B-cell lymphoma-2; BCL2L1, BCL2 like 1; BAX, BCL2-associated X protein; BAK, BCL2 antagonist/killer; BIM, BCL2-like 11; CYCD1, cyclin D1.

combination. In addition, pAkt (Ser473) protein levels were significantly decreased following treatment with API-1 in these cells for 24 and $48 \mathrm{~h}$. Additionally, combined treatment with FR and API-1 significantly inhibited Akt activation, indicated by the decrease in the phosphorylation of Akt at 24 and $48 \mathrm{~h}$. The protein level of pAkt, however, was markedly decreased by treatment with API-1 alone and the combination of FR and API-1 at $48 \mathrm{~h}$ in DLD-1 cells.

\section{Discussion}

The PI3K/Akt and Raf/MEK/ERK pathways are critical signal transduction pathways for regulating cell survival, proliferation, differentiation, migration, motility, metabolism and drug resistance (31-33). Mutationally activated or inactivated components of these pathways give rise to oncogenic transformation of the normal cells and cause a variety of cancers, such as CRC, melanoma, and lung, pancreatic and breast cancers (33-35). Therefore, numerous chemotherapeutic regimens targeting Ras downstream effectors are widely-adopted strategy for clinical success (35-37). Numerous studies have shown that inhibition of the components one signaling pathway leads to hyperactivation of another signaling pathways and addresses the issue of resistance, positive feedback mechanisms and resulting in increased toxicity $(38,39)$. Therefore, combinational therapy regimens targeting PI3K/Akt and Raf/MEK/ERK effectors appear to be improved therapeutic approaches to 
A

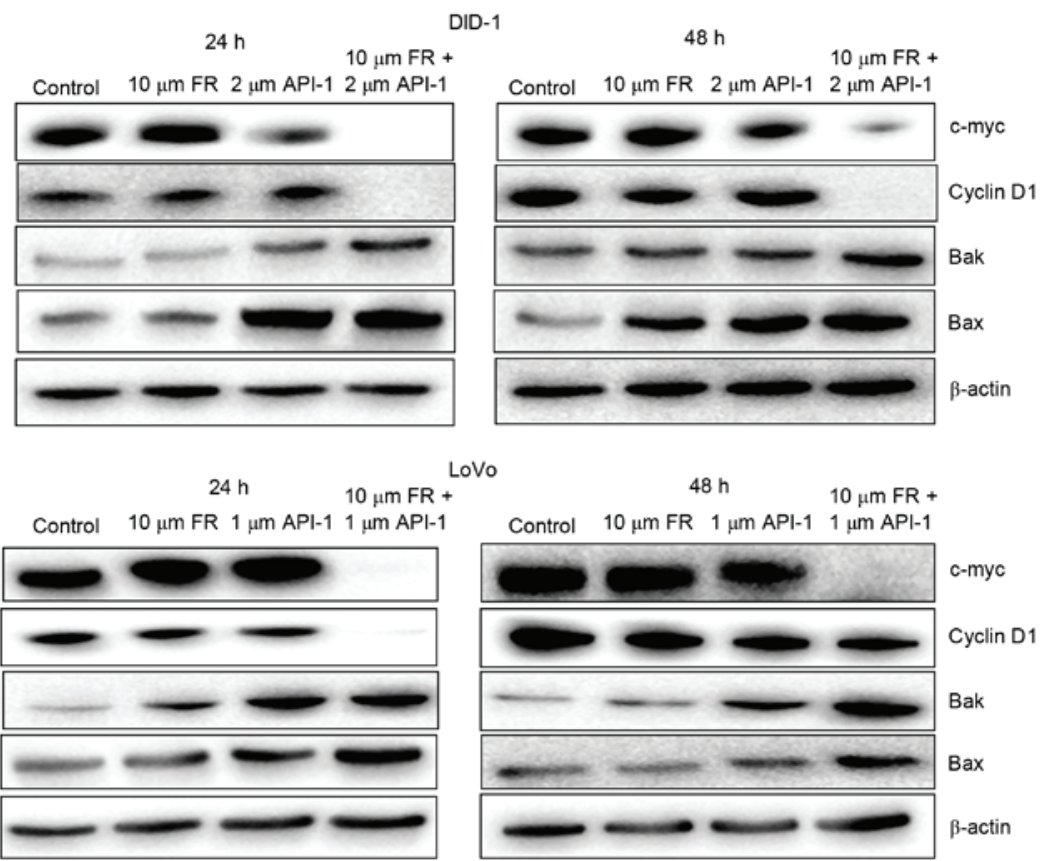

Figure 8. Effect of FR and API-1 alone or in combination treatment on the protein expression of BAX, BAK, cyclin D1 and cMYC in (A) DLD-1 and (B) LoVo cells at 24 and $48 \mathrm{~h}$, as measured by western blot analysis. The reference protein $\beta$-actin was used as an internal loading control. FR, FR180204; API-1, 4-amino-5,8-dihydro-5-oxo-8- $\beta$-D-ribofuranosyl-pyrido[2,3-d]pyrimidine-6-carboxamide; BCL2, B-cell lymphoma-2; BAX, BCL2-associated X protein; BAK, BCL2 antagonist/killer.

A

$24 \mathrm{~h}$

DLD-1

Control $10 \mu \mathrm{m} \mathrm{FR} 2 \mu \mathrm{m} \mathrm{API}-1 \quad 10 \mu \mathrm{m} \mathrm{FR}+$

Control $10 \mu \mathrm{m}$ FR $2 \mu \mathrm{m} \mathrm{API}-1 \quad \begin{aligned} & 10 \mu \mathrm{m} \mathrm{FR}+ \\ & 2 \mu \mathrm{m} \mathrm{API}-1\end{aligned}$
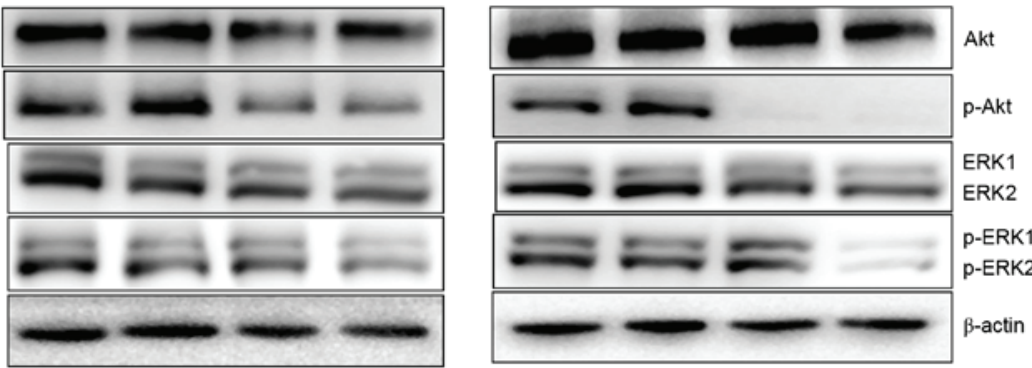

B

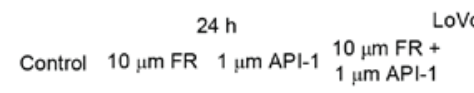

$\begin{array}{ccc}48 \mathrm{~h} & \\ \text { Control } & 10 \mu \mathrm{m} \mathrm{FR} \quad 1 \mu \mathrm{m} \mathrm{API}-1 & 10 \mu \mathrm{m} \mathrm{FR}+ \\ 1 \mu \mathrm{m} \mathrm{API}-1\end{array}$
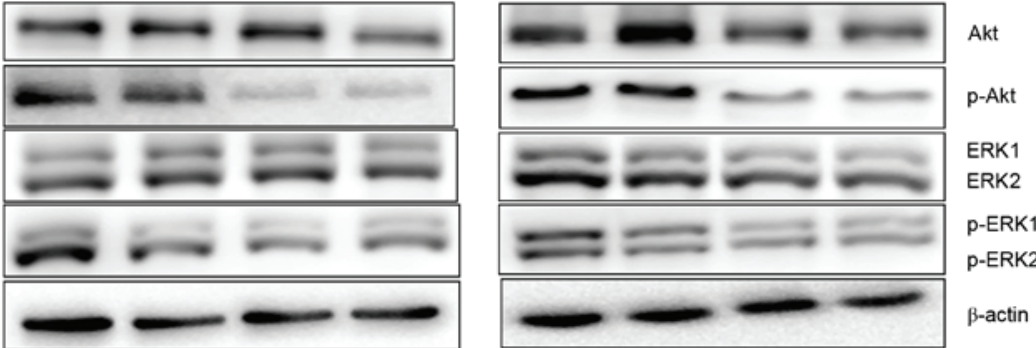

Figure 9. Effect of treatment with FR and API-1 alone or in combination on on intracellular signaling pathways in (A) DLD-1 and (B) LoVo cells. Cells were treated with the indicated concentrations of these agents for 24 and $48 \mathrm{~h}$ and protein levels of p-Akt, total Akt, p-ERK1/2 and total ERK1/2 were assayed by western blot analysis. The reference protein $\beta$-actin was used as an internal loading control. FR, FR180204; API-1, 4-amino-5,8-dihydro-5-oxo-8- $\beta$-D-ribofuranosyl-pyrido[2,3-d]pyrimidine-6-carboxamide; Akt, v-akt murine thymoma viral oncogene homolog; p-Akt, phosphorylated Akt; ERK1/2, extracellular signal-regulated kinase 1/2; p-ERK1/2, phosphorylated ERK1/2.

inhibit cell proliferation and induce apoptosis (19,39-41). The present study aimed to investigate the apoptotic and anti-proliferative effects of the selective Akt inhibitor API-1 and selective ERK1/2 inhibitor FR in DLD-1 and LoVo CRC cells. According to previous studies, DLD-1 cells harbor a constitutively active mutation in PIK3CA, which evokes 
resistance to monotherapy regimens (42). Briefly, the present study mainly focused on the effects of different concentrations of API-1 combined with a randomized concentration of FR. In the literature, the antiproliferative effects of FR were also evaluated at concentrations of $10-50 \mu \mathrm{M}$ FR in various cancer cell lines, including adrenocortical, mesothelioma, prostate, pancreatic and CRC cell lines, via inhibiting ERK1/2 in an ATP-competitive manner (25,43-47). In the study by Ohori et al (25), it was noted that FR was selective for ERK1/2 at concentrations $<30 \mu \mathrm{M}$ compared to another kinases, such as human recombinant MAPK kinase 1 , MAPK kinase 4 , IкB kinase $\alpha$, protein kinase $\mathrm{C} \alpha$, Src, Syc and platelet-derived growth factor $\alpha$ (25). Therefore, the lower concentration of FR $(10 \mu \mathrm{M})$ was chosen for single and combination regimens to eliminate the possible non-selective kinase inhibitory effects of FR, in the DLD-1 and LoVo cell lines.

Several studies have described the effects of API-1 as a single agent or in combination with other inhibitors of cell proliferation and/or cell death in various cancer cells $(24,48,49)$. In the study by Li et al (24), it was demonstrated that significantly decreased cell viability and induced apoptosis in 3 different non-small cell lung carcinoma and 3 various head and neck squamous cell carcinoma cell lines following API-1 treatment. This study found that treatment with API-1 sensitized these 6 cells to apoptosis in a PI3K/Akt-dependent manner. The antiproliferative response of these cells to API-1 was determined to be dose-dependent, and increased cell death was observed subsequent to exposure to API-1 for 72 h (24). Similarly, Toulany et al (49) showed that treatment with API-1 in human lung adenocarcinoma cells inhibited cell viability and enhanced radiation-dependent apoptosis. Dirican et al (46) investigated the possible synergistic cytotoxic/apoptotic effects of docetaxel and thymoquinone (TQ) in the presence of $10 \mu \mathrm{M}$ FR in DU-145 cells and drug-refractory prostate cancer cells. It was identified that the ERK1/2 inhibitor FR enhanced the combination treatment of docetaxel and TQ effects on inhibition of cell viability (46). Additionally, Doghman and Lalli (47) showed that FR treatment alone in 3 different adrenocortical carcinoma cell lines reduced cell viability. This study also found that FR and BEZ-235 combination treatment reduced the viability of LoVo cells more than single-agent treatments (47). Furthermore, as shown in Fig. 1C and F, when elimination of the synergistic crosstalk mechanism between the ERK and Akt pathways via FR was attempted, it was observed that the resistance mechanism in DLD-1 cells appeared to be activated in a time-dependent manner. As previously reported, inhibiting the ERK signaling pathway leads the hyperactivation of the Akt signaling pathway and vice versa $(38,39)$. This may be the cause of the increase in LoVo cell viability at $10 \mu \mathrm{M} \mathrm{FR}+\geq 3 \mu \mathrm{M}$ API-1 at $24 \mathrm{~h}$. Concentrations of $10 \mu \mathrm{M}$ FR $+2 \mu \mathrm{M}$ API-1 for DLD-1 cells and $10 \mu \mathrm{M} \mathrm{FR}+1 \mu \mathrm{M}$ API- 1 for LoVo cells were therefore used as optimal combination regimens at $24 \mathrm{~h}$ for DLD-1 cells and $48 \mathrm{~h}$ for LoVo cells. To support the WST assay results, cytotoxicity analysis was performed using a commercial kit that measures the amount of $\mathrm{LDH}$ released from damaged cells. According to Fig. 3, the levels of LDH leakage were increased with the rising concentrations of treatment with single agents at $24 \mathrm{~h}$ in DLD-1 cells, but at $48 \mathrm{~h}$ in LoVo cells. Additionally, LoVo cells demonstrated an increased response to FR and FR + API-1 treatments compared with DLD-1 cells at each time interval.

Induction of apoptosis in cancer cells has already been used as key indicator for the efficacy of a chemotherapeutic agent $(50,51)$. Cells undergo typical morphological changes during apoptosis and can be detected using specific dyes, such as AO/EB. Therefore, the present study aimed to elucidate whether the cells undergo apoptosis or necrosis with single and/or combination treatment. The present fluorescent microscopy results showed that LoVo cells were much more susceptible to apoptosis than DLD-1 cells with FR treatment. In addition, when FR treatment was combined with API-1 treatment, the apoptotic ratio was significantly increased in a dose-dependent manner. The proapoptotic effects of FR and/or API-1 in CRC cells were further confirmed using the Cell Death Detection ELISA assay, which is more sensitive to detect apoptosis rather than necrosis. In LoVo cells, API-1 treatment synergistically increased the DNA fragmentation ratio of the FR treated cells, particularly at $48 \mathrm{~h}$. By contrast, treatment with $2 \mu \mathrm{M}$ AP-1 alone appeared to induce apoptosis in more DLD-1 cells compared with the combination regimens at $48 \mathrm{~h}$. Overall, the apoptotic cell ratio and DNA fragmentation results suggested that when FR treated cells were administered with low dose API-1, the ERK pathway was inhibited at first, which led to hyperactivation of Akt pathway via crosstalk mechanisms; API-1 has limited activity to overcome the resistance and crosstalk mechanisms. However, increased concentrations of API-1 showed a significant proapoptotic profile and eliminated the compensatory mechanisms in FR-treated CRC cells, but the DNA fragmentation ratio at $48 \mathrm{~h}$ in DLD-1 cells was not significantly increased. In addition, as mentioned in the results section, when DLD-1 cells were treated with FR and API-1, cleaved caspase-3 levels were elevated in a dose-dependent manner at $24 \mathrm{~h}$, but not at $48 \mathrm{~h}$. By contrast, LoVo cells were more susceptible to caspase-dependent cell death at $48 \mathrm{~h}$. However, when compared to the DNA fragmentation results, DLD-1 cells appeared to have possible alternative apoptotic mechanisms along with caspase mediated cell death. In accordance with the present results, Hong et al showed that DLD-1 cells may undergo caspase-independent apoptosis via mitochondrial ROS production and JNK activation when apoptosis-associated speck-like protein containing a caspase recruitment domain (ASC) gene, which is epigenetically silenced in numerous human cancers, was reactivated (52). Additionally, Nakagawa et al demonstrated that the phytochemical $\alpha$-mangostin induces apoptosis by reducing mitochondrial membrane potential and increasing endonuclease- $\mathrm{G}$ mediated nucleosomal DNA fragmentation (53). Therefore, the present study aimed to reveal whether mitochondrial BCL2 family members were associated with apoptotic cell death subsequent to single-agent and combination treatment via mRNA and protein analysis.

Several studies have suggested that FR exerts inhibitory effects against several cancer cell lines via suppression of ERK1/2 phosphorylation $(43,45,47,54)$. For example, Doghman and Lalli (47) showed that the protein level of pERK was decreased, but the level of total ERK was not altered, in FR-treated adrenocortical cancer cells induced by BEZ235 in vitro (47). Another study revealed that treatment with FR blocked the phosphorylation and subsequent nuclear 
translocation of ERK1/2 in response to EGF stimulation in U138 glioblastoma cells (43). In addition, it has been found that treatment with FR reduced ERK1/2 phosphorylation in Caco-2, HCT-116 and SW-620 CRC cell lines (45). API-1 inhibits phosphorylation of Akt by binding to the $\mathrm{PH}$ domain of Akt, preventing phosphorylation at Thr308 and Ser473 and blocking the recruitment of Akt to the plasma membrane. In the present study, it was observed that phosphorylated Akt (Ser473) was downregulated, but the level of total Akt was not altered in LoVo cells treated with API-1 alone and API-1 + FR. Similar results were also found in several cancer cells, and it was found that treatment with API-1 decreased the level of p-Akt, but total Akt levels were not changed $(23,24)$. Additionally, the present study found the proapoptotic BAX, BAK and BIM mRNA levels were significantly increased following treatment with API-1 alone and in combination with FR treatment. However, the levels of antiapoptotic BCL2 and BCL2L1 were significantly decreased following combination treatment in DLD-1 and LoVo cells at 24 and $48 \mathrm{~h}$. Additionally, the western blot results supported that treatment with API-1 alone and in combination with FR activates mitochondrial apoptotic pathways. By contrast, the changes in the mRNA and protein levels of BCL2 family members following treatment with FR or API-1 alone showed that the PI3KCA-wild-type LoVo cells were more susceptible to apoptosis compared with DLD-1 cells. Combination treatment appeared to be an alternative therapeutic approach for each CRC cell line.

CYCD1 is an important cell cycle regulator that facilitates the transition between $\mathrm{G} 1$ and $\mathrm{S}$ phase and is overexpressed in the majority of cancer cells, such as CRC $(48,55)$. The cMYC protooncogene, usually implicated in cell transformation, differentiation and cell-cycle progression, also has a central role in certain forms of apoptosis. However, these two markers are regulated mainly by the Raf/MEK/ERK pathways, and the expression of the markers was not significantly changed at mRNA and protein levels subsequent to $10 \mu \mathrm{M}$ FR treatment. However, API-1 + FR treatment regimens significantly decreased cMYC levels, which prevented proliferation in each cell line. In addition, CYCD1 mRNA and protein levels were reduced subsequent to treatment of the two cell lines with API-1 and FR, with the exception of mRNA levels of LoVo cells at $48 \mathrm{~h}$. The reduction in CYCD1 levels made it difficult for cells to enter to the $\mathrm{S}$ phase. In addition, the results of BrdU incorporation, which is a key marker for the DNA synthesis rate at $\mathrm{S}$ phase, also revealed that cell cycle arrest did not completely occur following combination treatment $(10 \mu \mathrm{M}$ FR $+2 \mu \mathrm{M}$ API-1 for DLD-1 cells and $10 \mu \mathrm{M}$ FR $+1 \mu \mathrm{M}$ API-1 for LoVo cells), as shown in the results section. The results of BrdU incorporation, which is a key marker for the DNA synthesis rate at $\mathrm{S}$ phase, revealed that cell cycle arrest did not completely occur following combination treatment in the cells, as shown in the results section. Flow cytometry analysis is required to reveal the cell cycle progression subsequent to FR and API-1 treatments in these cell lines.

The Raf/MEK/ERK and PI3K/Akt signaling pathways are deregulated in various human cancers, including CRC. Therefore, the components of these signaling cascades are attractive targets for the treatment of CRC. The current study showed that combination treatment with the selective Akt inhibitor API-1 and selective ERK1/2 inhibitor FR prevents proliferation and induces apoptosis compared to single treatment in vitro via deregulating the crosstalk mechanisms. Additional analyses are required to elucidate the effects of combination regimens on cell cycle progression, cell proliferation and apoptosis in vitro and in vivo.

\section{Acknowledgements}

The present study was supported by The Scientific and Technological Research Council of Turkey (grant number 111S054).

\section{References}

1. Siegel RL, Miller KD and Jemal A: Cancer statistics, 2015. CA Cancer J Clin 65: 5-29, 2015.

2. Inoue-Choi M, Lazovich D, Prizment AE and Robien K: Adherence to the World Cancer Research Fund/American Institute for Cancer Research recommendations for cancer prevention is associated with better health-related quality of life among elderly female cancer survivors. J Clin Oncol 31: 1758-1766, 2013.

3. Haggar FA and Boushey RP: Colorectal cancer epidemiology: Incidence, mortality, survival, and risk factors. Clin Colon Rectal Surg 22: 191-197, 2009.

4. Bardhan K and Liu K: Epigenetics and colorectal cancer pathogenesis. Cancers (Basel) 5: 676-713, 2013.

5. van Engeland M, Derks S, Smits KM, Meijer GA and Herman JG: Colorectal cancer epigenetics: Complex simplicity. J Clin Oncol 29: 1382-1391, 2011.

6. Yu FZ, Yu BH, Li DL, Ke HL, Guo XZ and Xiao XY: PI3K expression and PIK3CA mutations are related to colorectal cancer metastases. World J Gastroenterol 18: 3745-3751, 2012.

7. Ye Q, Cai W, Zheng Y, Evers BM and She QB: ERK and AKT signaling cooperate to translationally regulate survivin expression for metastatic progression of colorectal cancer. Oncogene 33: 1828-1839, 2014.

8. Zhang J, Roberts TM and Shivdasani RA: Targeting PI3K signaling as a therapeutic approach for colorectal cancer. Gastroenterology 141: 50-61, 2011.

9. Fearon ER: Molecular genetics of colorectal cancer. Annu Rev Pathol 6: 479-507, 2011.

10. Yu M and Grady WM: Therapeutic targeting of the phosphatidylinositol 3-kinase signaling pathway: Novel targeted therapies and advances in the treatment of colorectal cancer. Therap Adv Gastroenterol 5: 319-337, 2012.

11. Franke TF, Kaplan DR and Cantley LC: PI3K: Downstream AKTion blocks apoptosis. Cell 88: 435-437, 1997.

12. Itoh $N$, Semba $S$, Ito $M$, Takeda $H$, Kawata $S$ and Yamakawa $M$ : Phosphorylation of Akt/PKB is required for suppression of cancer cell apoptosis and tumor progression in human colorectal carcinoma. Cancer 94: 3127-3134, 2002.

13. Arcaro A and Guerreiro AS: The phosphoinositide 3-kinase pathway in human cancer: Genetic alterations and therapeutic implications. Curr Genomics 8: 271-306, 2007.

14. Luo J, Manning BD and Cantley LC: Targeting the PI3K-Akt pathway in human cancer: Rationale and promise. Cancer Cell 4: 257-262, 2003.

15. Daouti S, Wang H, Li WH, Higgins B, Kolinsky K, Packman K, Specian A Jr, Kong N, Huby N, Wen Y, et al: Characterization of a novel mitogen-activated protein kinase kinase $1 / 2$ inhibitor with a unique mechanism of action for cancer therapy. Cancer Res 69: 1924-1932, 2009.

16. Yang SH, Sharrocks AD and Whitmarsh AJ: MAP kinase signalling cascades and transcriptional regulation. Gene 513: 1-13, 2013.

17. Lange F, Franz B, Maletzki C, Linnebacher M, Hühns M and Jaster R: Biological and molecular effects of small molecule kinase inhibitors on low-passage human colorectal cancer cell lines. Biomed Res Int 2014: 568693, 2014.

18. Cossa G, Gatti L, Cassinelli G, Lanzi C,Zaffaroni N and Perego P: Modulation of sensitivity to antitumor agents by targeting the MAPK survival pathway. Curr Pharm Des 19: 883-894, 2013.

19. De Luca A, Maiello MR, D'Alessio A, Pergameno M and Normanno N: The RAS/RAF/MEK/ERK and the PI3K/AKT signalling pathways: Role in cancer pathogenesis and implications for therapeutic approaches. Expert Opin Ther Targets 16 (Suppl 2): S17-S27, 2012. 
20. Gollob JA, Wilhelm S, Carter C and Kelley SL: Role of Raf kinase in cancer: Therapeutic potential of targeting the Raf/MEK/ERK signal transduction pathway. Semin Oncol 33: 392-406, 2006.

21. Dhillon AS, Hagan S, Rath O and Kolch W: MAP kinase signalling pathways in cancer. Oncogene 26: 3279-3290, 2007.

22. McCubrey JA, Milella M, Tafuri A, Martelli AM, Lunghi P, Bonati A, Cervello M, Lee JT and Steelman LS: Targeting the Raf/MEK/ERK pathway with small-molecule inhibitors. Curr Opin Investig Drugs 9: 614-630, 2008.

23. Kim D, Sun M, He L, Zhou QH, Chen J, Sun XM, Bepler G, Sebti SM and Cheng JQ: A small molecule inhibits Akt through direct binding to Akt and preventing Akt membrane translocation. J Biol Chem 285: 8383-8394, 2010.

24. Li B, Ren H, Yue P, Chen M, Khuri FR and Sun SY: The novel Akt inhibitor API-1 induces c-FLIP degradation and synergizes with TRAIL to augment apoptosis independent of Akt inhibition. Cancer Prev Res (Phila) 5: 612-620, 2012.

25. Ohori M, Kinoshita T, Okubo M, Sato K, Yamazaki A Arakawa H, Nishimura S, Inamura N, Nakajima H, Neya M, et al: Identification of a selective ERK inhibitor and structural determination of the inhibitor-ERK2 complex. Biochem Biophys Res Commun 336: 357-363, 2005

26. Batista LF, Roos WP, Christmann M, Menck CF and Kaina B: Differential sensitivity of malignant glioma cells to methylating and chloroethylating anticancer drugs: p53 determines the switch by regulating xpc, ddb2, and DNA double-strand breaks. Cancer Res 67: 11886-11895, 2007.

27. Boult J, Roberts K, Brookes MJ, Hughes S, Bury JP, Cross SS, Anderson GJ, Spychal R, Iqbal T and Tselepis C: Overexpression of cellular iron import proteins is associated with malignant progression of esophageal adenocarcinoma. Clin Cancer Res 14: 379-387, 2008

28. Livak KJ and Schmittgen TD: Analysis of relative gene expression data using real-time quantitative PCR and the $2^{-\Delta \Delta C}$ method. Methods 25: 402-408, 2001.

29. Anadol E, Kanca H, Yar AS, Helvacioğlu F, Menevşe S, Calgüner E and Erdoğan D: Prostaglandin F receptor expression in intrauterine tissues of pregnant rats. J Vet Sci 15: 125-131, 2014.

30. Pfaffl MW, Horgan GW and Dempfle L: Relative expression software tool (REST) for group-wise comparison and statistical analysis of relative expression results in real-time PCR. Nucleic Acids Res 30: e36, 2002.

31. Brown KK and Toker A: The phosphoinositide 3-kinase pathway and therapy resistance in cancer. F1000Prime Rep 7: 13, 2015.

32. Wang Y, Kaiser CE, Frett B and Li HY: Targeting mutant KRAS for anticancer therapeutics: A review of novel small molecule modulators. J Med Chem 56: 5219-5230, 2013.

33. Britten CD: PI3K and MEK inhibitor combinations: Examining the evidence in selected tumor types. Cancer Chemother Pharmacol 71: 1395-1409, 2013.

34. Cox AD, Fesik SW, Kimmelman AC, Luo J and Der CJ: Drugging the undruggable RAS: Mission possible? Nat Rev Drug Discov 13: 828-851, 2014.

35. Baines AT, Xu D and Der CJ: Inhibition of Ras for cancer treatment: The search continues. Future Med Chem 3: 1787-1808, 2011.

36. Takashima A and Faller DV: Targeting the RAS oncogene. Expert Opin Ther Targets 17: 507-531, 2013.

37. Gysin S, Salt M, Young A and McCormick F: Therapeutic strategies for targeting ras proteins. Genes Cancer 2: 359-372, 2011.

38. Watanabe T, Kobunai T, Yamamoto Y, Matsuda K, Ishihara S, Nozawa $K$, Iinuma $H$, Ikeuchi $H$ and Eshima K: Differential gene expression signatures between colorectal cancers with and without KRAS mutations: Crosstalk between the KRAS pathway and other signalling pathways. Eur J Cancer 47: 1946-1954, 2011.
39. Steelman LS, Chappell WH, Abrams SL, Kempf RC, Long J, Laidler P, Mijatovic S, Maksimovic-Ivanic D, Stivala F, Mazzarino MC, et al: Roles of the Raf/MEK/ERK and $\mathrm{PI} 3 \mathrm{~K} / \mathrm{PTEN} / \mathrm{Akt} / \mathrm{mTOR}$ pathways in controlling growth and sensitivity to therapy-implications for cancer and aging. Aging (Albany NY) 3: 192-222, 2011.

40. McCubrey JA, Steelman LS, Chappell WH, Abrams SL, Wong EW, Chang F, Lehmann B, Terrian DM, Milella M, Tafuri A, et al: Roles of the Raf/MEK/ERK pathway in cell growth, malignant transformation and drug resistance. Biochim Biophys Acta 1773: 1263-1284, 2007.

41. Ye Q and She QB: Integration of AKT and ERK signaling pathways in cancer: Biological and therapeutic implications. J Pharmacol Clin Toxicol 1: 1009, 2013.

42. Morrow CJ, Gray A and Dive C: Comparison of phosphatidylinositol-3-kinase signalling within a panel of human colorectal cancer cell lines with mutant or wild-type PIK3CA. FEBS Lett 579: 5123-5128, 2005.

43. Mut M, Lule S, Demir O, Kurnaz IA and Vural I: Both mitogen-activated protein kinase (MAPK)/extra ellular-signal-regulated kinases (ERK) $1 / 2$ and phosphatidylinositide-3-OH kinase (PI3K)/Akt pathways regulate activation of E-twenty-six (ETS)-like transcription factor 1 (Elk-1) in U138 glioblastoma cells. Int J Biochem Cell Biol 44: 302-310, 2012.

44. Honda M, Kanno T, Fujita Y, Gotoh A, Nakano T and Nishizaki T: Mesothelioma cell proliferation through autocrine activation of PDGF- $\beta \beta$ receptor. Cell Physiol Biochem 29: 667-674, 2012.

45. Ragusa M, Statello L, Maugeri M, Majorana A, Barbagallo D, Salito L, Sammito M, Santonocito M, Angelica R, Cavallaro A, et al: Specific alterations of the microRNA transcriptome and global network structure in colorectal cancer after treatment with MAPK/ERK inhibitors. J Mol Med (Berl) 90: 1421-1438, 2012

46. Dirican A, Atmaca H, Bozkurt E, Erten C, Karaca B and Uslu R: Novel combination of docetaxel and thymoquinone induces synergistic cytotoxicity and apoptosis in DU-145 human prostate cancer cells by modulating PI3K-AKT pathway. Clin Transl Oncol 17: 145-151,2015.

47. Doghman M and Lalli E: Efficacy of the novel dual PI3-kinase/mTOR inhibitor NVP-BEZ235 in a preclinical model of adrenocortical carcinoma. Mol Cell Endocrinol 364: 101-104, 2012.

48. Kim JK and Diehl JA: Nuclear cyclin D1: An oncogenic driver in human cancer. J Cell Physiol 220: 292-296, 2009.

49. Toulany M, Kehlbach R, Florczak U, Sak A, Wang S, Chen J, Lobrich M and Rodemann HP: Targeting of AKT1 enhances radiation toxicity of human tumor cells by inhibiting DNA-PKcs-dependent DNA double-strand break repair. Mol Cancer Ther 7: 1772-1781, 2008.

50. Asakura T and Ohkawa K: Chemotherapeutic agents that induce mitochondrial apoptosis. Curr Cancer Drug Targets 4: 577-590, 2004.

51. Elmore S: Apoptosis: A review of programmed cell death. Toxicol Pathol 35: 495-516, 2007.

52. Hong S, Hwang I, Lee YS, Park S, Lee WK, Fernandes-Alnemri T, Alnemri ES, Kim YS and Yu JW: Restoration of ASC expression sensitizes colorectal cancer cells to genotoxic stress-induced caspase-independent cell death. Cancer Lett 331: 183-191, 2013.

53. Nakagawa Y, Iinuma M, Naoe T, Nozawa Y and Akao Y: Characterized mechanism of alpha-mangostin-induced cell death: Caspase-independent apoptosis with release of endonuclease-G from mitochondria and increased miR-143 expression in human colorectal cancer DLD-1 cells. Bioorg Med Chem 15: 5620-5628, 2007.

54. Tan BJ and Chiu GN: Role of oxidative stress, endoplasmic reticulum stress and ERK activation in triptolide-induced apoptosis. Int J Oncol 42: 1605-1612, 2013.

55. Takuwa N and Takuwa Y: Regulation of cell cycle molecules by the Ras effector system. Mol Cell Endocrinol 177: 25-33, 2001. 